\title{
ZNACZENIE ANALOGII DLA OKREŚLENIA PUNKTU WYJŚCIA W QUARTA VIA
}

\begin{abstract}
W artykule nawiązuje się do ożywionej dyskusji dotyczącej roli i znaczenia czwartej drogi świętego Tomasza z Akwinu (quarta via) dla filozofii klasycznej. W dyskusji tej do chwili obecnej wykrystalizowały się dwa stanowiska. W jednym postrzega się czwartą drogę jako nawiązanie i kontynuację myśli platońskiej, przez co widzi się w argumencie zagrożenie dla jednolitości filozofii klasycznej. W innym czwarta droga jest postrzegana jako sam rdzeń metafizyki realistycznej, która zmierza do całościowego i ostatecznego wyjaśnienia rzeczywistości. Właśnie czwarta droga jest traktowana w takim wyjaśnieniu jako ostatni wieńczący etap.

Autor niniejszej pracy wskazuje na powód rozbieżności zdań w kwestii roli i znaczenia czwartej drogi w filozofii klasycznej. Utrzymuje, że w argumencie święty Tomasz nie określił jasno, jakie doświadczalne własności stanowią punkt wyjścia argumentu. W samym argumencie jest mowa o wielu ustopniowanych własnościach, ale tylko niektóre $\mathrm{z}$ nich mogą spełniać funkcję dowodową. Jeśli więc wszystkie wymienione w argumencie doświadczalne własności realnego bytu uczyni się jego punktem wyjścia bądź wybierze się tylko niektóre spośród nich, a te będą nieodpowiednie, wówczas quarta via nie będzie mogła niczego ostatecznościowo wyjaśniać/dowieść. W artykule wskazuje się na analogię jako klucz do ustalenia katalogu ustopniowanych własności realnego bytu, będących odpowiednim punktem wyjścia dla quarta via. Na jej podstawie ustala, że katalog tworzą tylko własności transcendentalne, gdyż jedynie te własności określa zasada analogii bytu, która wiąże byty przygodne, określone przez te własności, z analogatem głównym.

Słowa kluczowe: analogia bytu, argumenty za istnieniem Boga, doskonałości bytowe, filozofia Boga, filozofia klasyczna, metafizyka, transcendentalia bytowe
\end{abstract}

\section{WSTEP}

W tomizmie ścierają się różne opinie na temat roli i znaczenia czwartej drogi świętego Tomasza $^{2}$. Jedni - jak Mieczysław Gogacz ${ }^{3}$ - drogę postrzegają jako zagrożenie dla jednolitości systemu tomistycznego, bowiem widzą w niej elementy filozofii platońskiej i neoplatońskiej ${ }^{4}$. Inni - jak Mieczysław A. Krapiec - drogę traktują jako zwornik i ostatni etap wyjaśnienia metafizycznego $\mathrm{W}$ filozofii tomistycznej. ${ }^{5} \mathrm{~W}$ tym ostatnim przypadku quarta via jest punktem odniesienia interpretacji pozostałych dróg. Powodem

\footnotetext{
${ }^{1}$ Ks. dr Andrzej Sołtys, Zakład Nauk Humanistycznych, Wydział Zarządzania, Politechnika Rzeszowska, ul. Poznańska 1, 35-084 Rzeszów, tel. 017 8651204, e-mail: asoltys@prz.edu.pl

${ }^{2}$ Św. Tomasz zamieszcza quarta via w Summa contra gentiles, I, 13 oraz w Summa theologica, I, q. 2, a. 3, c. Punktem odniesienia w niniejszej pracy jest tekst quarta via zamieszczony w Summa theologica, I, q. 2, a. 3, c.

${ }^{3}$ http://www.tomizm.pl/?q=node/22

${ }^{4}$ Twierdzenie na temat doskonałości cząstkowej, wskazującej na doskonałość absolutną bezsprzecznie pochodzi z Platońskiej Uczty (210b-211a).

${ }^{5}$ Por. M.A. Krąpiec, Teoria analogii bytu, Redakcja Wydawnictw KUL, Lublin 1993, s.162..
} 
przeciwstawnych interpretacji quarta via jest głównie rozbieżność stanowisk w kwestii jej doświadczalnego punktu wyjścia. Wybór własności stanowiących punkt wyjścia w quarta via zdaje się przesądzać o znaczeniu tej drogi dla metafizyki realistycznej. Być może kluczem umożliwiającym wyłonienie takich własności będzie analogia.

$\mathrm{Na}$ centralny charakter doktryny analogii w quarta via wskazuje praca Marion Wagner ${ }^{6}$. W pierwszej części pracy Wagner analizuje tradycyjne interpretacje quatra via, natomiast część drugą poświęca własnej analizie i interpretacji wspomnianej drogi. W tej części pracy zmierza do ustalenia metafizycznej bazy tego dowodu. Jest przekonana, że stanowi ją doktryna analogii, natomiast następstwami tej doktryny są partycypacja i przyczynowość ${ }^{7}$. Jednakże powiedzieć, że analogia jest kluczem w interpretacji czwartej drogi, to nic innego, jak tylko wytyczyć kierunek, w jakim ta powinna zmierzać. Jakkolwiek intuicja Wagner w odniesieniu do klucza interpretacyjnego quarta via wydaje się słuszna, tak już dokonana przez nią interpretacja tej drogi jest obciążona licznymi założeniami, co wystawia argument na zarzut niekonkluzywności ${ }^{8}$.

Utrzymujemy, że interpretacja quarta via powinna przebiegać $\mathrm{w}$ taki sposób, aby doprowadziła do wskazania racji leżących w samym argumencie, które będą przemawiały za potraktowaniem analogii jako właściwego klucza interpretacyjnego. Wtedy analogię będzie można uznać za klucz interpretacyjny quarta via, gdy ta będzie spajała wszystkie elementy struktury quarta via. Znaczy to, że w jej interpretacji kluczem może być tylko taki typ analogii, który nada jednolity i konkluzywny charakter quarta via. Najważniejszą sprawą w tym przedsięwzięciu będzie odkrycie właściwej ontycznej podstawy w quarta via. Wysuwamy hipotezę, że analogia jest odpowiednim narzędziem, które pomoże wskazać właściwe doświadczalne własności stanowiące punkt wyjścia quarta via. Wskazywanie na takie własności musi być jednak uzgodnione $\mathrm{z}$ wyborem takiego typu analogii, która nada tej drodze systemowy, metafizyczny i konkluzywny charakter. Czyli $\mathrm{z}$ jednej strony postrzegamy $\mathrm{w}$ analogii zasadę spajająca argument klimakologiczny, $\mathrm{z}$ drugiej natomiast nie wiemy, jaki typ analogii stanowi wspomnianą zasadę. Wraz z odkrywaniem właściwego punktu wyjścia quarta via spodziewamy się, że wyłoni się też typ analogii stanowiącej jej zasadę.

\section{WŁASNOŚCI ILOŚCIOWE W PUNKCIE WYJŚCIA QUARTA VIA?}

Punktem wyjścia quarta via są stopnie doskonałości ${ }^{9}$. Takie dane określa zasada analogii. W argumencie zasada analogii została wyrażona stwierdzeniem ,istnieje w rzeczach coś, co jest mniej lub więcej..." ${ }^{10}$. Byty są do siebie podobne przez to, że mają te same własności doskonałościowe. W porządku tych samych własności byty różnią się

\footnotetext{
${ }^{6}$ Zob. M. Wagner, Die philosophischen Implikate der „quarta via”. Eine Untersuchung zum vierten Gottesbeweis bei Thomas von Aquin (S.Th. I, q. 2, a. 3, c.), E. J. Brill, Leyde - New York Copenhague - Cologne 1989.

7 ,...diese Verschränkung von Partizipations- und Kausalitätsbeziehung macht ihr Wesen aus”. Ibidem, s. 79.

${ }^{8}$ Por. A. Côté, La question du fondement métaphysique dans la quarta via de Thomas d'Aquin. À propos d'un livre récent, „Revue Philosophique de Louvain. Quatrième série” 1992/86, s. 209. 9 „Quarta via sumitur ex gradibus qui in rebus inveniuntur”. Św. Tomasz z Akwinu, Summa theologica, I, q. 2, a. 3, c.

10 „Invenitur enim in rebus aliquid magis et minus bonum, et verum, et nobile : et sic de aliis huiusmodi”. Ibidem.
} 
między sobą stopniem, w jakim te w rzeczach się przejawiają. Interpretując ten argument trzeba rozstrzygnąć, czy owo „mniej i więcej” w odniesieniu do własności bytu, stanowiące podstawę czwartej drogi, odnosi się do wszystkich rodzajów gradacji czy tylko niektórych.

Są tacy, jak choćby Van Steenberghen, którzy przypisują świętemu Tomaszowi intencję najszerszego potraktowania bazy empirycznej ${ }^{11}$. Na tor myślenia o najszerszych warunkach początkowych argumentu naprowadza święty Tomasz poprzez przykład z ogniem wskazywanym jako maksimum ciepła, uznanym za przyczynę rozprzestrzeniania się ciepła na inne rzeczy. Van Steenberghen przyjął na tej podstawie, że zasada analogii w argumencie odnosi się przede wszystkim do własności doskonałościowych bytu o charakterze ilościowym ${ }^{12}$. To właśnie $w$ grupie tych własności znajduje się fizyczna $i$ mierzalna własność ciepła. Byty mające tę własność pozostają w ilościowym stosunku do źródła ciepła tworząc tym samym proporcjonalne struktury o charakterze ilościowym.

Proporcjonalnie analogicznie człony o charakterze ilościowym są wobec siebie izomorficzne. Znaczy to, że relacje P i Q mają jedynie identyczne własności formalne, natomiast pod względem treści nie muszą mieć nic wspólnego, co można zapisać ( $\exists \mathrm{P}$, $\mathrm{Q}) \cdot \mathrm{f}$ P x · g Q y · P smor $\mathrm{Q}^{13}$. Jeśli natomiast zwiążemy z ilościowymi kresami relacji jakąśs wspólną mierzalną treść, w naszym wypadku może nią być fizyczna własność ciepła, to uzyskujemy następujący zapis $(\exists \mathrm{P}, \mathrm{Q}) \cdot \mathrm{f} \mathrm{P} x \cdot \mathrm{f} \mathrm{Q}$ y $\cdot \mathrm{P}$ smor $\mathrm{Q}^{14} \cdot \mathrm{W}$ pierwszym wypadku znaną strukturą $\mathrm{P}$ można wyjaśniać nieznaną dotąd strukturę $\mathrm{Q}$ ze względu na identyczne własności formalne obydwu struktur. W drugim zaś różne są analogaty przyporządkowane do tej samej mierzalnej, analogicznej i proporcjonalnej treści. Jednakże podobnie jak w pierwszym wypadku między P i Q zachodzi izomorfia, gdyż pod względem formalnym $\mathrm{P}$ i Q są identyczne, mimo że kresy dla P i Q nie są te same. Kresy Q mogą być wielokrotnością kresów P bądź odwrotnie. Jednakże relacja P i Q zachowuje tę samą proporcję. Izomorfia znosi podobieństwo, zastępując je identycznością. Co jest charakterystycznego w zarysowanej analogii będącej również zasadą fizycznej własności ciepła?

Fizyczna własność ciepła ma charakter kategorialny. Jest własnością wyłącznie bytów materialnych. Czy zatem taką własność można traktować jako właściwą empiryczną bazę dla quarta via? Wprawdzie przyjmuje się, ze względu na „mniej i więcej” w odniesieniu do tej własności jej analogiczny charakter, ale izomorfia formalnych analogicznych członów nie uprawnia do wychodzenia poza wspomniane analogiczne struktury. Analogia w odniesieniu do mierzalnej i stopniowalnej własności ciepła ma jedynie charakter deskryptywny, nie implikuje natomiast żadnej postaci rozumowania o analogacie głównym. W konsekwencji wątpliwe jest to, czy zarysowane formy proporcjonalności

\footnotetext{
${ }^{11}$ Por. F. Van. Steenberghen, Dieu caché. Comment savons-nous que Dieu existe?, Louvain 1966, s. 81.

${ }^{12}$ Por. ibidem.

${ }^{13}$ Symbolem ,smor” oznaczyliśmy izomorficzność relacji P i Q zachodzących między przedmiotami „,x" i ,y” a proporcjonalnie odpowiadającej im różnej treści „,f” i ,g”.

${ }^{14}$ Symbolem „,smor” oznaczyliśmy izomorficzność relacji P i Q zachodzących między przedmiotami „,x” i „y” a odpowiadającej im wspólnej proporcjonalnej treści „,f”. Por. Z. Wolak, Analogia w filozofii i nauce, „Zagadnienia Filozoficzne w Nauce” 2002/30, s. 97-98. Symbol smor oznaczający izomorfizm relacji został utworzony od łacińskiego wyrażeniea „similis ordine”.
} 
można w ogóle uznać za analogiczne ${ }^{15}$. Krapiec nazywa je pozorną analogią, gdyż analogiczność występuje w nich jedynie w zewnętrznym kształcie, który przybiera postać izomorfii bądź homomorfii. Tymczasem mamy tu $\mathrm{w}$ gruncie rzeczy do czynienia $\mathrm{z}$ relacjami ilościowo-jednoznacznymi ${ }^{16}$. Zaznaczmy, że jednoznaczność i wieloznaczność przeciwstawiają się analogiczności. Jeśli więc zasada analogii nie określa wewnętrznie fizycznej i mierzalnej własności ciepła, a tym samym nie daje ontycznych podstaw do analogicznego rozumowania o analogacie głównym ${ }^{17}$, to nie można tej własności uznać za odpowiedni ontyczny fundament dla quarta via. Zasada analogii wyklucza własność fizycznego ciepła $\mathrm{z}$ grupy tych, które stanowią ontyczny fundament w quarta via. Natomiast uznanie tej własności za ontyczną podstawę w dowodzeniu pozbawia argument konkluzywności. Wywód ten dostatecznie tłumaczy, dlaczego niektórzy współcześni komentatorzy odmawiają argumentowi wartości poznawczej. W kontekście uznawania mierzalnej własności ciepła za doskonałość współtworzącą ontyczny fundament dla quarta via trudno się nie zgodzić z Van Steenbergenem, który podważa dowodową wartość tego argumentu ${ }^{18}$. Autor ten utrzymuje, że istnienie różnych stopni jakiejś doskonałości nie może dowodzić istnienia wartości najwyższej, podobnie jak istnienie ludzi bardziej i mniej bogatych nie wyznacza maksymalnej granicy bogactwa ${ }^{19}$.

Literalna interpretacja argumentu prowadzi do błędnego określenia punktu wyjścia quarta via. Wniosek, że mamy takie maksimum, z którego rozprzestrzenia się ciepło i jest nim ogień jako źródło ciepła jest wnioskiem zdroworozsądkowym. Tymczasem argumentacja świętego Tomasza nie jest zdroworozsądkową, lecz filozoficzną i systemową. Filozofia docieka natury wspomnianej własności i rozpoznaje, że ta ma charakter ilościowy. Stąd zapytamy, czy proporcjonalna własność ciepła w poszczególnych materialnych rzeczach domaga się jakiegoś kresu, jednego maksimum. Otóż nie, podobnie jak proporcje liczbowe zestawiane ze sobą nie implikują żadnej proporcji stanowiącej kres wszystkich pozostałych. Nie można przeoczyć faktu, że różnicę między analogicznymi członami w tej analogii wprowadza wyłącznie proporcjonalne w stosunku do analogatów zwielokrotnienie tej ilościowej własności. W gruncie rzeczy w punkcie wyjścia argumentacji nie byłoby gradacji uznawanej przez świętego Tomasza za doświadczalną bazę argumentu, lecz równość. Nasuwa się tu pytanie, jaki jest $\mathrm{w}$ takim razie sens przykładu $\mathrm{z}$ ogniem przedstawianym $\mathrm{w}$ argumencie przez świętego Tomasza jako maksimum ciepła.

Wagner w swej pracy wyjaśnia, że przykład nie ma w argumencie znaczenia merytorycznego, lecz tylko poglądowe i dydaktyczne. Akwinata poprzez przykład z ogniem jedynie zilustrował główne twierdzenie. Zabieg taki wprowadził ze względu na

\footnotetext{
${ }^{15}$ Arystoteles nazywa je analogicznymi. Stanowią one postać analogii matematycznej, polegającej na równym, jednoznacznym stosunku występującym między różnymi grupami wielkości, jak też w grupie wielkości ciagłych. Zob. Arystoteles, Etyka nikomachejska, 1. 5, c. 5 - 1131 a9-b24.

${ }^{16}$ Por. M. A. Krapiec, Analogia, [w:] Powszechna encyklopedia filozofii, red. A. Maryniarczyk i in., Polskie Towarzystwo Tomasza z Akwinu, Lublin 2000, s. 213.

${ }^{17}$ Wagner konstatuje, że już samo mówienie o maksimum liczbowym jest absurdalne. Podobnie stwierdza Mieczysław A. Krapiec, Metafizyka, TN KUL, Lublin 1988, s. 490.

${ }^{18}$ Por. F. Van Steenberghen, op. cit., s. 176-180; A. Côté, op. cit., s. 207.

${ }^{19}$ Por. F. Van Steenberghen, op. cit., s. 81.
} 
adresatów, do których tę argumentację kierował ${ }^{20}$. Między innymi z tego powodu nie nazywał on quinque viae dowodami, lecz drogami bądź argumentami, gdyż te zawierały sporo bogatszą treść niż wymagał tego dowód. Właśnie przykład z ogniem stanowi tę pleonastyczną treść, która w argumencie nie spełnia żadnej funkcji dowodowej. Natomiast uczynienie z własności ciepła doświadczalnego punktu wyjścia spowoduje, że quarta via utraci swoją centralną pozycję w metafizyce tomistycznej, nic bowiem nie będzie dowodzić ani nic ostatecznościowo wyjaśniać. Nie będziemy wówczas wiedzieli, na czym spoczywa onus probandi argumentu. Trzeba się jeszcze przyjrzeć własnościom rodzajowym, czy te $\mathrm{z}$ kolei mogą być doskonałościami stanowiącymi punkt wyjścia w quarta via.

\section{WŁASNOŚCI RODZAJOWE I GATUNKOWE W PUNKCIE WYJŚCIA QUARTA VIA?}

Kwestia doskonałości rodzajowych jako punktu wyjścia dla quarta via jest obecna w samym argumencie ${ }^{21}$. To na tej podstawie komentujący argument analizują także zagadnienie doskonałości rodzajowych pod kątem możliwości uczynienia $\mathrm{z}$ nich doświadczalnego punktu wyjścia. Badając tę kwestię, powinniśmy rozstrzygnąć, czy doskonałości rodzajowe tworzą gradacje bytowe, a jeśli tworzą, to jaka jest ich ostateczna racja. Spróbujmy posłużyć się narzędziem analogii w badaniu tego zagadnienia.

Jeśli doskonałości rodzajowe układałyby byty w stopnie, znaczyłoby to, że te mają charakter analogiczny. Dałoby to następnie podstawę do zbadania, jaki typ analogii poznania mógłby być użyty w odniesieniu do tych własności, aby można było wskazać ich bytową rację. W quarta via święty Tomasz zdaje się postępować przybliżoną już metodą. Otóż własności w punkcie wyjścia musi określać zasada analogii, gdyż tylko własności o charakterze analogicznym układają poszczególne byty w stopnie ${ }^{22}$. Jeśli więc określałaby je zasada analogii, to kolejnym krokiem będzie systemowe uniesprzecznienie tych własności.

Quarta via, ale też pozostałe drogi należące do quinquae viae mają znaczenie systemowe. Znaczy to, że ich głównym celem nie jest udowodnienie prawdziwości zdania, że Bóg jest, ale metafizyczne wyjaśnienie badanych aspektów rzeczywistości. A to $\mathrm{z}$ kolei per occasionem prowadzi do odkrycia przyporządkowania do jednego. Przyporządkowanie do jednego, czyli wskazanie na ontyczny związek z analogatem głównym, to najważniejszy cel, jaki stawia analogii święty Tomasz z Akwinu. Świadczą o tym jego liczne synonimiczne wyrażenia: unum et alterum vel utrumque ad tertium, per ordinem ad unum, per prius et posterius, secundum magis et minus ${ }^{23}$. Odkrycie takiego przyporządkowania i jego unaocznienie kończą proces metafizycznego uniesprzecznienia badanych aspektów realnego bytu. Zarysowane kroki postępowania są obecne w quarta via i $\mathrm{w}$ nich wyjaśnia się ustopniowanie własności w realnych bytach. W takiej

\footnotetext{
${ }^{20}$ Święty Tomasz posługiwał się w swoich pracach wspomnianymi ilustrującymi przykładami ze względu na szersze grono adresatów i to one są nierzadko powodem rozbieżnych interpretacji głównych jego twierdzeń. Por. A. Côté, op. cit., s. 207.

${ }^{21}$ „Quod autem dicitur maxime tale in aliquo genere, est causa omnium quae sunt illius generis...”. Św. Tomasz z Akwinu, Summa theologica, I, q. 2, a. 3, c.

${ }^{22}$ „Quarta via sumitur ex gradibus qui in rebus inveniuntur”. Ibidem.

${ }^{23}$ Por. C. Giacon, La seconda scolastica, I grandi commentatori di San Tommaso, t. I, Milano 1944, s. 119.
} 
systemowej i metafizycznej perspektywie trzeba ustawić własności o charakterze rodzajowym i gatunkowym i rozpoznać, czy mogą one stanowić doświadczalny punkt wyjścia w quarta via. Do grupy doskonałości rodzajowych należą między innymi takie doskonałości, jak rozumność, zwierzęcość, życie, materialność, substancjalność. Jeśli mają one stanowić punkt wyjścia, to najpierw trzeba określić, w jaki sposób łączą one poszczególne byty, a następnie ustalić, czy posiadana własność hierarchizuje przygodne byty między sobą.

Arystoteles w swej Metafizyce wskazuje na różne typy jedności. Najpierw odróżnia jedność przypadkową i jedność istotową. Z kolei w jedności istotowej odróżnia jedność numeryczną, gatunkową, rodzajową i analogiczną ${ }^{24}$. W świetle tych odróżnień zarówno doskonałości rodzajowe, jak i gatunkowe nie tworzą jedności przypadkowej, lecz istotową. Pomiędzy typami jedności istotowej zachodzi wstępujący stosunek asymetrycznej zależności. Byty jedne gatunkowo są tym samym jedne rodzajowo, jedne numerycznie zaś są tym samym jedne gatunkowo, w końcu byty jedne rodzajowo zakładają typ jedności analogicznej. Jedność analogiczna jest najszerszym typem jedności między bytami, utworzonej przez naturalny, wspólny, stały i nieprzypadkowy typ przyporządkowania. Jak więc widać, byty wiążą się ze sobą poprzez określające je analogiczne własności, które ustawiają poszczególne byty w porządku hierarchicznym.

Dopiero w wyniku zabiegu abstrakcji zastosowanej do tych własności wyodrębnia się własności rodzajowe i gatunkowe. Jednak własności te nie mają już analogicznego charakteru, ale są jednoznacznymi kategoriami należącymi do porządku poznania ${ }^{25}$. Jeśli więc nie określa ich już zasada analogii, to tym samym nie są one własnościami hierarchizującymi poszczególne byty. W sensie ścisłym nie mamy tu już do czynienia z gradacją, lecz równością. A zatem takie własności jak zwierzęcość, rozumność, materialność, substancjalność nie podlegają stopniowaniu. Własności rodzajowe i gatunkowe nie mogą być więc uznane za fundament quarta via. Są tego dwa powody. Jednym jest to, że argument mieszałby wtedy porządek poznawczy z porządkiem bytowym. Tymczasem intencją świętego Tomasza było, aby związać argument $\mathrm{z}$ porządkiem bytowania. Innym powodem jest, że skoro tych własności nie określa zasada analogii, to tym samym nie tworzą one stopni. A zatem quarta via, będąc argumentem ze stopni doskonałości, ex definitione wyklucza ze swojego katalogu stanowiącego doświadczalny punkt wyjścia własności nieustopniowane. I chociaż można przy użyciu tych własności zbudować analogiczne proporcje, to jednak analogony współtworzące proporcjonalne człony w tej analogii nie będą przyporządkowane do jednego.

\section{WŁASNOŚCI TRANSCENDENTALNE W PUNKCIE WYJŚCIA QUARTA} VIA

Badacze interpretujący argument klimakologiczny są zgodni, że jego punktem wyjścia są własności transcendentalne ${ }^{26}$. Na podstawie racji przedstawionych $\mathrm{w}$ niniejszej pracy twierdzimy, że punktem wyjścia badanego argumentu są tylko własności transcendentalne. Czyniąc je punktem wyjścia, argument uzyskuje wysoki stopień

\footnotetext{
${ }^{24}$ Por. Arystoteles, Metafizyka, 1. 5, c. 6 - 1016 b 30.

${ }^{25}$ Będąc sposobami orzekania czegoś o desygnatach, noszą nazwę kategoremów. Por. M. Kowalewski, Logika, Poznań 1959, s. 79-82.

${ }^{26}$ Por. L. J. Elders, Filozofia Boga, Agencja Wydawnicza Katolików MAG, Warszawa 1992, s. 117-127; S. Kowalczyk, Filozofia Boga, RW KUL, Lublin 1995, s. 137.
} 
spójności, a ponadto zdaje się wiernie odzwierciedlać intencję jego twórcy. W pojmowaniu transcendentaliów święty Tomasz odszedł od traktowania ich jako najwyższych orzeczników. Widział w nich natomiast modi essendi entis ${ }^{27}$. Jeśli więc święty Tomasz explicite wskazał transcendentalia jako punkt wyjścia argumentu, a te interpretował metafizycznie, to tym samym wypowiedział swoją intencję, aby również argument rozumieć ściśle metafizycznie. Nie jest przy tym jasne, czy święty Tomasz uczynił punktem wyjścia quarta via wszystkie transcendentalia bytowe, czy też niektóre. W argumencie bowiem nie wymienia wszystkich transcendentaliów, ale tylko te, które ukazują byt w przyporządkowaniu do intelektu i woli osoby. Nie wspomina natomiast o transcendentaliach, które charakteryzują byt sam w sobie, czyli o tak zwanych transcendentaliach absolutnych. Wagner jest zdania, że święty Tomasz zawarł je w słowach sic de aliis. Jej zdaniem w tym wyrażeniu święty Tomasz zawarł swoją intencję, aby punktem wyjścia uczynić wszystkie własności transcendentalne ${ }^{28}$. Wydaje się, że kwestia obecności transcendentaliów absolutnych w punkcie wyjścia quarta via jest drugorzędna, wszystkie własności transcendentalne bowiem jednakowo określa zasada analogii i każda z tych własności hierarchizuje poszczególne byty przygodne. Natomiast problemy interpretacyjne $\mathrm{w}$ argumencie nasuwa własność oznaczona pojęciem nobile. Werbalnie nie należy ona do tradycyjnego katalogu transcendentaliów bytowych. Dlaczego jednak święty Tomasz umieścił nobile $\mathrm{w}$ bezpośrednim sąsiedztwie bonum i verum $^{29}$ ? Jak interpretować to pojęcie, aby jego rozumienie było zgodne $\mathrm{z}$ myślą świętego Tomasza?

Wskazywane w argumencie nobile jest rozmaicie interpretowane. Jedni pojmuja je jako dostojeństwo bytu, inni jako etyczną sprawnośćc ${ }^{30}$. W konsekwencji tych komentatorskich rozbieżności Van Steenberghen sprowadził to pojęcie do metafory ${ }^{31}$. Tymczasem wątpliwości dotyczące rozumienia nobile ustępują, gdy się zaczyna postrzegać quarta via w perspektywie systemowej. Wówczas traktuje się quarta via nie tyle jako argument na istnienie Boga, ale w pierwszym rzędzie jako metodę w metafizycznym wyjaśnianiu rzeczywistości. Właśnie $\mathrm{w}$ taki sposób postrzegał ten argument święty Tomasz. A zatem trudne do przyjęcia jest identyfikowanie nobile $\mathrm{z}$ etyczną sprawnością. $Z$ tym pojęciem należy raczej wiązać własność metafizyczną i transcendentalną podobnie jak sąsiadujące $\mathrm{z}$ nim pojęcia transcendentalne tworzące najbliższy jego kontekst.

Przekonanie to potwierdza Elders, utrzymując, że święty Tomasz posługuje się tym terminem w sensie ontologicznym. W związku z tym nobile oznacza według Eldersa tę własność bytu, która odsłania się poprzez spontaniczne porównywanie ze sobą takich elementów ontycznej struktury bytu jak substancja i przypadłość, przyczyna i skutek bądź jeszcze innych. W efekcie takiego zabiegu substancja jawi się jako bardziej szlachetna niż

\footnotetext{
${ }^{27}$ Por. A. Maryniarczyk, Transcendentalia, [w:] Powszechna encyklopedia filozofii, red. A. Maryniarczyk i in., Polskie Towarzystwo Tomasza z Akwinu, Lublin 2009, s. 534-535.

${ }^{28}$ Por. A. Côté, op. cit., s. 208.

29 „Invenitur enim in rebus aliquid magis et minus bonum, et verum, et nobile, et sic de aliis huiusmodi”. Św. Tomasz z Akwinu, Summa theologica, I, q. 2, a. 3, c. Termin ten można przełożyć jako to, co doskonałe bądź szlachetne. Por. S. Kowalczyk, op. cit., s. 136.

${ }^{30}$ Kowalczyk skłania się do etycznej interpretacji nobile. Ibidem, s. 137.

${ }^{31}$ Por. F. Van Steenberghen, Le problème de l'existence de Dieu dans les écrits de S. Thomas d'Aquin, Louvain-la-Neuve 1980, s. 209.
} 
przypadłość, przyczyna bardziej szlachetna niż skutek ${ }^{32}$. Wtedy szlachetność występuje jako własność określająca wszystkie elementy ontycznej struktury bytu. Z racji proporcjonalnego rozłożenia tej własności w poszczególnych elementach ontycznej struktury bytu szlachetność jest własnością analogiczną, spełniając tym samym warunek konieczny dla możliwości uznania jej za punkt wyjścia w quarta via. Ale nie wiemy jeszcze, czy tak rozumiana własność nobile jest przyporządkowana do jednego, a więc czy implikuje analogat główny jako swoją ostateczną rację. Dopiero rozstrzygnięcie tej kwestii przesądzi, czy nobile pojęte jako szlachetność może stanąć w punkcie wyjścia quarta via.

Z wypowiedzi Eldersa można wywnioskować, że pojmuje on nobile jako akt każdej formy elementów struktury bytu porównywanych ze sobą ${ }^{33}$. Ale wtedy ostateczną racją dla nobile przypadłości czy substancji jest właśnie forma każdego z tych elementów metafizycznej struktury i ona określa miarę możliwego zaktualizowania się tej własności. Jednakże wtedy własność nobile nie postuluje istnienia analogatu głównego jako zewnętrznej, ontycznej racji uzasadniającej jej analogiczny charakter w poszczególnych elementach struktury bytu kategorialnego. Zróżnicowany stopień opisywanej własności w elementach ontycznej struktury bytu wyjaśnia się wewnętrznie. Nobile w tej interpretacji nie jest pojęciem określającym własność transcendentalną. A w związku z tym interpretacja rozchodzi się $\mathrm{z}$ intencją świętego Tomasza, który umieścił nobile $\mathrm{w}$ bezpośrednim sąsiedztwie transcendentalnej prawdy i transcendentalnego dobra.

Kontekst występowania nobile podpowiada, aby wiązać z tym pojęciem własność transcendentalną. Należy tylko ustalić, do jakiej własności to pojęcie odsyła. Wagner odchodzi od słownikowego interpretowania tego pojęcia. Twierdzi, że skoro święty Tomasz umieścił nobile w tym samym szeregu co prawdę i dobro, to tym samym nie tylko wskazał, że jest to własność transcendentalna, lecz także określił, że własność ta należy do grupy transcendentaliów relacyjnych ${ }^{34}$. $\mathrm{Z}$ tego wynika, że nobile jest po prostu synonimem transcendentalnej własności piękna ${ }^{35}$. Wiążącym argumentem na rzecz tego przekonania jest - zdaniem Wagner - wspólna określająca wszystkie te transcendentalia zasada analogii obecna na wszystkich etapach quarta via.

Rzeczywiście zasada analogii określa własności transcendentalne w realnych bytach przygodnych. Konsekwencją tego są gradacje bytowe. Miarę dla stopni w analogicznie pojętym bycie wyznaczają zróżnicowane pod względem treści analogaty. A zatem stopnie istnienia i własności transcendentalnych mają charakter jakościowy (treściowy). Są zawsze proporcjonalne do ściśle zdeterminowanej treści poszczególnych analogatów. Jakkolwiek poszczególne analogaty są aktualizowane przez proporcjonalne do nich analogony (istnienie i własności transcendentalne), to jednak analogaty w analogicznie pojętym bycie nie są ich ontyczną racją. Dowodzi tego realna różnica między istotą $\mathrm{i}$ istnieniem, istotą a własnościami transcendentalnymi. A zatem $\mathrm{w}$ analogicznie pojętym bycie istnienie $\mathrm{i}$ związane $\mathrm{z}$ nim transcendentalne własności są jedynie $\mathrm{w}$ różnym stopniu partycypowane przez poszczególne analogaty. Stopnie partycypowania każdego z analogatów w istnieniu i własnościach transcendentalnych domagają się zaafirmowania

\footnotetext{
${ }^{32}$ Por. L. J. Elders, op. cit., s. 119.

${ }^{33}$ Forma jest aktem w stosunku do odpowiadającego jej elementu możnościowego w bycie.

${ }^{34}$ Święty Tomasz nazwał transcendentaliami relacyjnymi te własności, które charakteryzują byt w przyporządkowaniu do intelektu i woli osoby. Zob. A. Maryniarczyk, op. cit., s. 535.

${ }^{35}$ Por. A. Côté, op. cit., s. 208.
} 
takiego analogatu, który już nie partycypuje, ale jest Istnieniem, Prawdą, Dobrem i Pięknem. Byt taki jest źródłem partycypacji.

Podsumowując trzeba stwierdzić, że quarta via świętego Tomasza z Akwinu staje się argumentem jednolitym, systemowym, metafizycznym i konkluzywnym dopiero wtedy, gdy jego doświadczalnym punktem wyjścia są transcendentalne własności bytu. Do takiego wniosku doprowadza interpretacja argumentu według klucza analogii.

\section{LITERATURA}

[1] Arystoteles, Etyka nikomachejska, przeł. D. Gromska. Wydawnictwo Naukowe PWN, Warszawa 2007.

[2] Arystoteles, Metafizyka, przeł. K. Leśniak, [w:] Dzieła wszystkie, t. 2, Państwowe Wydawnictwo Naukowe, Warszawa 1990, s. 602-857.

[3] Côté A., La question du fondement métaphysique dans la quarta via de Thomas d'Aquin. À propos d'un livre récent, „Revue Philosophique de Louvain. Quatrième série" 1992/86, s. 206-210.

[4] Elders L. J., Filozofia Boga, Agencja Wydawnicza Katolików MAG, Warszawa 1992.

[5] Giacon C., La seconda scolastica, I grandi commentatori di San Tommaso, t. I, Milano 1944.

[6] Kowalczyk S., Filozofia Boga, Redakcja Wydawnictw KUL, Lublin 1995.

[7] Kowalewski M., Logika, Pallottinum, Poznań 1959.

[8] Krapiec M. A., Analogia, [w:] Powszechna encyklopedia filozofii, red. A. Maryniarczyk i in., Polskie Towarzystwo Tomasza z Akwinu, Lublin 2000, s. 210-220.

[9] Krąpiec M. A., Metafizyka: zarys teorii bytu, Redakcja Wydawnictw KUL, Lublin 2000.

[10] Krapiec M. A., Teoria analogii bytu, Redakcja Wydawnictw KUL, Lublin 1993.

[11]Krąpiec M. A., Metafizyka - ogólna teoria rzeczywistości, [w:] Wprowadzenie do filozofii, red. M. A. Krąiec, S. Kamiński, Z. J. Zdybicka i inni, Redakcja Wydawnictw KUL, Lublin 1996.

[12] Maryniarczyk A., Transcendentalia, [w:] Powszechna encyklopedia filozofii, red. A. Maryniarczyk i in., Polskie Towarzystwo Tomasza z Akwinu, Lublin 2009, s. 533-542.

[13] Montaignes B., La doctrine de l'analogie de l'être d'après Saint Thomas d'Aquin, Paris 1963.

[14]Platon, Uczta, przeł. W. Witwicki, Wydawnictwo Marek Derewecki, Kęty 2006.

[15] Sołtys A., Poznanie Boga na drodze analogii $w$ myśli wybranych przedstawicieli tomizmu egzystencjalnego, „Resowia Sacra” 2002/2003, s. 25-36.

[16] Steenberghen Van F., Dieu caché. Comment savons-nous que Dieu existe?, Louvain 1966.

[17] Steenberghen Van F., Le problème de l'existence de Dieu dans les écrits de S. Thomas d'Aquin, Louvain-la-Neuve 1980. 
[18] Św. Tomasz z Akwinu, Summa contra gentiles, t. 2, Casa Editrice Marietti, Roma-Torino 1946.

[19] Tomasz z Akwinu, Traktat o Bogu, Summa teologii, kwestie 1-26, przeł. G. Kurylewicz, Z. Nerczuk, M. Olszewski, Wydawnictwo Znak, Kraków 1999.

[20] Wagner M., Die philosophischen Implikate der „quarta via”. Eine Untersuchung zum vierten Gottesbeweis bei Thomas von Aquin (S.Th. I, q. 2, a. 3, c.), E. J. Brill, Leyde - New York - Copenhague - Cologne 1989.

[21] Wolak Z., Analogia w filozofii i nauce, „Zagadnienia Filozoficzne w Nauce” 2002/30.

\section{THE IMPORTANCE OF ANALOGY TO DETERMINE THE STARTING POINT IN QUARTA VIA}

The article refers to the ongoing debate on the fourth argument (quarta via) of St. Thomas Aquinas, which leads to the affirmation of the existence of God. In the debate until now emerged two positions on the role and importance of the fourth argument for classical philosophy. According to the first position the fourth argument St. Thomas Aquinas is seen as one who adopts and develops the Platonic philosophy. Then this argument may threaten the unity of classical philosophy. There are also others who perceive the fourth argument as the core of realistic metaphysics.

The purpose of the fourth argument St. Thomas Aquinas is the complete and final explanation of reality. Undoubtedly, the fourth argument is treated as the last stage of holistic explanation of reality. The author of this study indicates the reasons of disagreement concerning the role and importance of the fourth argument for classical philosophy. In his opinion, the cause of these discrepancies is that St. Thomas did not specify clearly those properties that can be the foundation of the argument. But how to choose them? In this paper, the author points to the analogy, this is key to the rejection of these properties, which can not constitute ontological base of the argument with of degrees perfections.

Keywords: analogy of being, arguments for God's existence, perfection of being, philosophy of God, classical philosophy, metaphysics, transcendental ownership.

DOI:10.7862/rz.2014.hss.29

Przesłano do redakcji: luty 2014

Przyjęto do druku: lipiec 2014 